world that there existed always also 'another West'. It also teaches them a lot about the spirit of resilience, perseverance, creativity and innovation, providing them with a wider and more comprehensive and holistic attitude toward Western civilisation.

\title{
Note
}

1. Christoph Marcinkowski, "Germany and the Muslim World", Islam and Civilisational Renewal 1, no. 3 (April 2010), 519-22. See also idem, “Toward 'Prussian Virtues': Transforming the Civil Service in Muslim Countries into a Factor of Political Stability", Islam and Civilisational Renewal 2, no. 4 (July 2011), pp. 717-22.

In May 2010, IAIS Malaysia and the German Embassy in Malaysia hosted an International Seminar on Germany and Islamic Culture, which was co-organised by this reviewer and where he delivered a lecture entitled "Germany and Islam: A Pictorial Journey Through Time".

\section{Mehran Kamrava (ed.), Innovation in Islam: Traditions and Contributions}

(Berkeley, Los Angeles, and London: University of California Press, 2011), xii+251 pp. ISBN: 978-0-520-26695-7. US\$24.95

\section{Tauseef Ahmad Parray Aligarh Muslim University, Aligarh, India}

Innovation in Islam - consisting of twelve chapters, eleven essays by a multidisciplinary group of leading scholars from across the world and a descriptive introductory chapter by the editor - offers in-depth analyses of the history, meaning and context, causes, consequences, and obstacles to innovation in Islam. Focusing on the ways and means through which the teachings of Islam have been produced and perpetuated over time, the contributors investigate such areas as the hermeneutics and epistemology, the arts and letters, jurisprudence, personal status, and Muslims' perceptions of the self in the modern world. Innovation in Islam illuminates a debate that extends beyond semantics into everyday politics and society - and one that has ramifications around the world.

The overriding objective of the book is to demonstrate that Islam, both as a worldview and as a comprehensive system of social and political organisation, is fundamentally 'adaptable', and therefore fundamentally 'applicable and relevant' to today's modern world. As the contributors demonstrate, writes Kamrava, it is not Islam per se that needs to change in order for it to once again become a leading source of - or at least context for - innovative change and progress in fields such as scientific and intellectual production and social and political organisation. For Kamrava, it is not in Islam itself that we must seek the answer to Bernard Lewis's rhetorical question What Went Wrong? ${ }^{1}$ Instead, the answer lies in the larger context within which Islam has historically found itself: in the ways in which knowledge about Islam has been acquired, accepted, and internalised, in perceptions about 
Islam that have developed and have become ingrained among both believers as well as non-Muslims, and in the reactive postures thus assumed worldwide in relation to Islam (see pp. 10-11).

Consisting of twelve chapters, the book is divided into three parts, viz. Part I: "The Intellectual Process" (chapters 2-4), Part II: "The Arts and Letters" (chapters 5-9), and Part III: "Islam in the Modern World" (chapters 10-12). Part I looks at the question of how knowledge of Islam is produced, accumulated, and given shape and direction, and what the current and future directions of Islamic thought, among both Sunni and Shi' ite thinkers, are likely to be. In a nutshell, it examines the intellectual processes involved in formulating knowledge of Islam and moving it forward. Part II concerns innovation in the literary and visual arts of Islam, while Part III expands on the context and institutions through which innovation in Islam has been made possible, and the reactions to and consequences of the interplay between and Islam and the modern world.

Chapter 1, "Contextualizing Innovation in Islam" (pp. 1-20) by Mehran Kamrava, spans over two main themes: The meaning and context of bid' $a$ and obstacles to innovation. The literal Arabic translation for 'innovation' is bid 'ah, a concept that over time has come to acquire a highly negative connotation. After discussing the relationship between innovation and bid ' $a$ h, and how the latter has come to acquire a negative, even dreaded connotation, this chapter shows that innovation in Islam is neither new nor novel; nor, indeed, has it been that rare. For Kamrava, the notion of bid'ah, though rarely mentioned in the Qur'ān, became prevalent soon after the death of the Prophet Muhammad to refer to "a belief or a practice for which there is no precedence in the time of Prophet" (p. 2).

In chapter 2, "Knowledge and Hermeneutics in Islam Today: Which Reform?" (pp. 23-38), Tariq Ramadan offers a critical examination of the ways in which Islamic knowledge and hermeneutics are accumulated today. Focusing specifically on the ways in which knowledge about and within Islam has been produced, accumulated, and transmitted, Ramadan also looks at those aspects of the religion's understanding and practice where reforms are needed. He rejects the proposition that the Qur'ân itself needs to be reformed, a proposition that, he claims, is becoming increasingly prevalent among certain academic circles in the West. Instead, he maintains, it is the hermeneutics of Islam and, more specifically, the historical operationalisation of certain key concepts - especially tajdìd and ișlăh (renewal and reform), and al-thäbit and al-mutaghayyir (the immutable and the changing) - that need to be rethought and reformulated.

Mohammed Arkoun, in chapter 3, "Deconstructing Epistēmē(s)" (pp. 39-57) taking Ramadan's arguments one step further - maintains that historically scholars have focused on the intellectual processes involved in the historical development of 'Islam'. We need to understand 'Islam' as the intellectual productions of Islamic 
thought, he argues. Western scholarship on Islam has considered the history of Islamic thought in the cognitive frame of a linear history of ideas and schools of thinking in each discipline, focusing mainly on the major texts of the formative and classical periods.

In chapter 4, "Iranian Shi 'ism at the Gates of Historic Change" (pp. 58-81), Mehran Kamrava focuses more specifically on the innovations that are currently taking place within Iranian Shi'a doctrine and jurisprudence. He chronicles the direction of Iranian Shi'ism after the country's 1978/79 revolution and the debates within it that have come to constitute what he labels as a "reformist religious discourse" or "religious reformist discourse" (see pp. 60, 63, 65, 66), particularly articulated by four of the country's most renowned religious intellectuals, namely, former president Muhammad Khatami, Mohammad Mojtahed Shabestari, Abdulkarim Soroush, and Mohsen Kadivar - each having different background, different approach, and concentration on different aspects of Twelver Shi' ite jurisprudence (p. 60).

Part II concerns innovation in the literary and visual arts of Islam, beginning with chapter 5, "History from Below, Dictionary from Below" (pp. 85-97) by Nelly Hanna, in which an examination of Yūsuf al-Maghribī's Raf' al- 'iṣr fì kalām ahl Mișr - an early seventeenth-century dictionary of the "colloquial speech of [Arabic language] of Cairo" - is made (p. 86), which is innovative because the author is more concerned with practice and words as they were used, rather than with the correct, or strict, dictionary meaning. Hanna concludes that al-Maghribī's work can be considered both "innovative for its period of treatment of colloquial Arabic" as worthy of scientific study; as well as a work that looked to the future in relation to the "cultural developments in the language" (p. 96).

In chapter 6, "The Translation of the Qur'an: An Impossible Task - The Classical Linguistic-Theological Roots of the Debate" (pp. 98-110), Nașr Abū-Zayd tackles the question of translation of the Qur'ān and the daily prayer (salāh). This is a topic to which he has paid considerable scholarly attention over the years and one that has caused him much controversy. ${ }^{2}$ Here in this essay, he poses a simple but central question: is the prayer understood to be the word of God itself, or is it meant to represent the meaning of God's word? Put differently, can the Qur'ān be read and understood in languages other than Arabic, especially in today's world, when a majority of Muslims around the globe happen to be non-Arabs? Abū-Zayd reaches the conclusion that since the Qur'ān is the supreme Arabic text, translation is not only "impossible but forbidden" and "What is allowed is translations of the 'meanings' for the sake of knowing and learning about Islam", but for "praying and performing religious duties, no translation is permitted" (p. 108).

Adonis (the pseudonym of the Syrian poet 'Alī Ahmad Sa 'īd Asbar), one of the Arab world's most celebrated contemporary poets, through examining the broader relationship between poetry and innovation in Islam, offers a frontal secularist 
assault on ossified conceptions of Islam, in his paper "Toward a New Understanding of Renewal in Islam" (ch. 7, pp. 111-24). As the embodiment of perfection, he argues, Islam saw no need for literary and poetic innovation, instead associating poets with the supernatural jinn. He argues that what Islam lacks sorely, and what it needs urgently, is "renewal" (tajaddud). He concludes that there is "no renewal, modernity, or poetry in the revelations", because modernity and poetry are the work of those Muslims who allowed "life and reality to triumph over text" (p. 123).

Focusing more specifically on Sufi poetry, Patrick Laude in chapter 8, "Creation, Originality, and Innovation in Sufi Poetry" (pp. 125-42), explores the spiritual function of poetry in Sufism as a paradoxical, ever-shifting mediation between presence and absence. Beginning with a consideration of the qur'ānic understanding of poetry as a problematic human activity that may give rise to pretension and hypocrisy, he proceeds to define the requirements of what he considers to be "an authentically Islamic" poetry. Laude maintains that Sufi poetry is not only the epitome of Islamic poetry, but is "innovative by espousing and suggesting the renewed creation of the instant, finding therein, without seeking it, the pristine originality of the Real" (p. 139).

Walter B. Denny in chapter 9, "Innovation in the Visual Arts of Islam" (pp. 143-63), focuses on innovation in Islamic visual arts. According to Denny, as "innovation does not exist without tradition" (p. 143), so innovation within tradition has been encouraged, respected, admired, and emulated from the first centuries of Islam, when a distinctive Islamic style emerged in art and architecture, down to the present day. What makes innovation in the Islamic artistic traditions distinctive, Denny argues, is the peculiar nature of interplay between innovation and tradition in different places and epochs. To examine how this interplay affects the creative process, Denny examines a number of specific cases: Islamic ceramics and the relationship between technical and artistic innovation; Islamic architecture and the relationship between engineering and spatial innovation; and the art of the Islamic carpet, deeply embedded in all social and economic levels of certain Islamic cultures, and often stereotyped as the most traditional of Islamic art forms. Denny reaches to three main conclusions (see p. 162).

Part III expands on the context and institutions through which innovation in Islam has been made possible, and the reactions to and consequences of the interplay between Islam and the modern world. Perceptions of Islam, its role and place in modernity, and particularly its relationship with the generic 'West' have been especially problematic in the post-9/11 world. Drawing readers' attention to the contemporary era and to realities as they currently affect Islam and Muslims in the West in general and in the United States in particular, Sherman A. Jackson in chapter 10, "Liberal/Progressive, Modern, and Modernized Islam: Muslim Americans and the American State" (pp. 167-89) looks at some of the most pressing issues related 
to perceptions, identity, and the self that Muslims in America face today. According to Jackson, even in the most learned circles of non-Muslim scholars and observers of Islam in the West, the notion that Muslims can fully indigenise their religion without compromising its fundamental constitution is challenged, if not rejected outright. There is, Jackson argues, the ever-present danger that "predatory reason and rationality" will continue to perpetuate the gap between Muslims and non-Muslims in America. And there is no reason to seek a "monolithic expression of Islam in America today"; nor is there "any need" to pursue a "monolithic expression of what it means to be "American"” (p. 185).

In chapter 11, "Hijab and Choice: Between Politics and Theology" (pp. 190-212), Ziba Mir-Hosseini draws attention to the issue of hijāb - the covering of a Muslim woman's head or face - and the politics and theology of this most visible Islamic mandate in Islamic fiqh (jurisprudence). She examines, from a critical feminist perspective, the evolution of the debates and juristic positions on hijāb in Islamic legal tradition. Focusing on the assumptions that underlie the rulings on hijāb in classical jurisprudence, she then proceeds to show, with special reference to Iran, how these assumptions have been "reproduced, challenged, and redefined in contemporary legal discourse" (p. 191). She discusses hijāb as 'protection', as 'protest', as 'imposition', and hijāb as 'choice'.

In the book's final chapter, "Modern Movements in Islam" (pp. 213-38), John O. Voll examines "Muslim movements in the modern era", which provide important examples of "innovation in Islamic history" (p. 213). The broader patterns of the development of these movements reflect the dynamism of the interactions between Islam and modernity, argues Voll, and it is important to look at the broader historical dynamics of these developments as well as to examine the specific movements within their own unique contexts. Over the past two centuries, according to Voll, a wide range of innovative adaptations have taken place in the nature of both Islamic movements and also in modernity itself. Beginning from Jamāl al-Dīn Afghān̄i (d. 1897) to the present day, he captures the history of Islamic movements in just 22 pages, but very comprehensively, constructively, and in an innovative style. This chapter reminds us of the importance of context for the extent to which adaptability and innovation may permeate Islam at a given time or place or, alternatively, may be divorced and distanced from it.

However, this writer feels that the book as a whole could have been strengthened in certain respects.

The book could have done with a conclusion, to match its strong, comprehensive, and innovative and informative introduction (which, for me, is a book in itself). This significant omission deprived Kamrava, the editor, of the opportunity to tie up loose ends and reinforce the main points made in the chapters (although every chapter has its own concluding remarks). It also denied the book a fitting climax. Moreover, the 
book has a useful bibliography and a well-organised index, but it lacks a glossary of key terms, which many laymen, and even most non-Muslim undergraduate and postgraduate students of Islam, would find to be an invaluable resource.

Collectively, the chapters in this book give us insights into the complexity of the issues surrounding the notion and manifestations of innovation in Islam. In this book, it becomes evident that 'innovation' and all that it implies remains deeply contested in Islam in the fields of literature and the arts, hermeneutics and epistēme, gender and race relations and representations, perceptions of 'the other', and Islam's place in the modern world. These chapters provide definitive answers to various questions that have long preoccupied observers and believers alike insofar as change and innovation within Islam are concerned.

In sum, this splendid collection of provocative essays - addressing the issues from several different perspectives and in various contexts - provides a broad introduction to the topic of innovation in Islam. There are many chapters that are actually 'must reads' for everyone interested in modern trends in Islamic thought.

\section{Notes}

1. Bernard Lewis, What Went Wrong? The Clash Between Islam and Modernity in the Middle East (Oxford: Oxford University Press, 2002).

2. Nașr Abū Zayd (an Egyptian Muslim thinker and one of the leading liberal theologians, famous for his project of a 'humanistic qur'ānic hermeneutics') has written various works on this theme both in Arabic and English; for example: Rationalism in Exegesis: A Study of the Problem of Metaphor in the Writing of the Mutazilites (Beirut and Casablanca, 1982); The Concept of the Text: A Study of the Qura'nic Sciences (Beirut and Cairo, 1991); The Problematic of Reading and the Method of Interpretation (Beirut and Casablanca, 1995); Rethinking the Qur'an: Towards a Humanistic Hermeneutics (Utrecht, 2004). He has also written various articles and essays on the same theme, among them "Linguistic Exposition of God in the Qur'ān", "The Textuality of the Koran", and "Divine Attributes in the Qur'an: Some Poetic Aspects".

\section{Alwi Shihab, Examining Islam in the West: Addressing Accusations and Correcting Misconceptions}

(Jakarta: PT Gramedia Putaka Utama Publishing, 2011), 258 pp.

ISBN: 978-979-22-6771-6. Rp77,900

\section{Zarina Nalla International Institute of Advanced Islamic Studies (IAIS) Malaysia}

This book is no doubt an eye-opener and reflects the thoughts of an individual who is unique: an academician with a passion for inter-religious understanding who was a former foreign minister of Indonesia and a graduate of two diametric worlds of education: the Middle East and the United States of America. 